\title{
Determination of antioxidant migration levels from polyethylene films into legumes
}

\section{Polietilen filmlerden baklagillere geçen antioksidanların saptanması}

\author{
Şana SUNGUR ${ }^{1 *}$, Çetin TUNUR ${ }^{1}(\mathbb{D})$ \\ ${ }^{1}$ Hatay Mustafa Kemal University, Science and Letters Faculty, Department of Chemistry, Hatay, Turkey
}

\section{To cite this article:}

Sungur, Ş. \& Tunur, Ç. (2020). Determination of antioxidant migration levels from polyethylene films into legumes. Harran Tarım ve Gıda Bilimleri Dergisi, 24(1): 26-32.

DOI:10.29050/harranziraat.590841

Address for Correspondence: Şana SUNGUR e-mail:

sungur@mku.edu.tr

Received Date:

11.07.2019

Accepted Date:

24.02.2020

(C) Copyright 2018 by Harran University Faculty of Agriculture. Available on-line at www.dergipark.gov.tr/harranziraat

\section{ABSTRACT}

Polyethylene packaging is a widely used packaging material in a wide range of foods such as bread, pulses, and meat products. These materials, which are produced in the form of small granules, are produced with different techniques depending on their usage area. Methods such as extrusion, blow molding and molding are the most frequently used of these production forms. As a result of some studies, it has been determined that some additives used during the production and called as masterbatch have a contact with food and they pass through food and beverages in this way. In this study, polyethylene samples containing 1000 ppm and 3000 ppm of Irganox 1010 (pentaerythritoltetrakis(3-(3,5-di-tert-butyl-4hydroxyphenyl) propionate) and Irganox 1076 (octadecyl 3-(3,5-di-tert-butyl-4-hydroxyphenyl) propionate) were prepared. Then, five different legume samples (rice, cracked wheat, corn, white beans, and chickpea) were sandwiched between two circular pieces of polyethylene films, with the contact layer facing the sample. Samples were stored at two different temperatures ( $4 \stackrel{\circ}{\circ}$ and $25 \stackrel{\circ}{\circ}$ ) for 30 days. Migration quantities were determined using GCMS and comparative evaluations were made. Migration amounts from polyethylene samples containing 1000 ppm Irganox 1010 at $4{ }^{\circ} \mathrm{C}$ are between 364-642 ppb, while migration amounts from polyethylene samples containing 1000 ppm Irganox 1010 are between 407 and 682 ppb. In these conditions, the highest migration was $682 \mathrm{ppb}$ from $3000 \mathrm{ppm}$ polyethylene to cracked wheat in 30 days, while the lowest migration was 364 ppb from 1000 ppm polyethylene to white beans in 10 days. Transitions from polyethylene samples containing $1000 \mathrm{ppm}$ Irganox 1010 at $25^{\circ} \mathrm{C}$ are in the range of $423-827 \mathrm{ppb}$, and the migration amounts from polyethylene samples of $3000 \mathrm{ppm}$ are in the range of 512 - $848 \mathrm{ppb}$. In these conditions, the highest migration was $848 \mathrm{ppb}$ from $3000 \mathrm{ppm}$ polyethylene to cracked wheat in 30 days, while the lowest migration was 423 ppb from 1000 ppm polyethylene to white beans in 10 days.

Key Words: Polyethylene packaging, Irganox 1010, Irganox 1076, Migration, Legume.

Öz

Polietilen paketleme, ekmek, bakliyat ve et ürünleri gibi çok çeşitli gıdalarda yaygın olarak kullanılan bir ambalaj malzemesidir. Küçük granül formunda üretilen bu malzemeler kullanım alanlarına bağlı olarak farklı tekniklerle üretilmektedir. Ekstrüzyon, şişirmeli kalıplama ve kalıplama gibi yöntemler bu üretim formlarında en sık kullanılanlardır. Bazı çalışmalar sonucunda, üretim sırasında kullanılan ve "masterbatch" olarak adlandırılan bazı katkı maddelerinin gıda ile temas ettiği ve bu şekilde yiyecek ve içeceklere geçtikleri tespit edilmiştir. Bu çalışmada, 1000 ppm ve 3000 ppm Irganoks 1010 ve Irganoks 1076 içeren polietilen örnekler hazırlandı. Daha sonra, beş farklı baklagil numunesi (pirinç, bulgur, mısır, kuru fasulye ve nohut) iki dairesel polietilen film parçası arasına yerleştirildi. Örnekler 30 gün boyunca farklı iki sıcaklıkta ( 4 으 and 25 으) depolandı. Migrasyon miktarları GC-MS aracılığıyla belirlendi ve birbirleriyle karşılaştırıldı. Elde edilen sonuçlara göre Irganox 1010'un 4 oC'de 1000 ppm'lik polietilen numunelerinden gerçekleşen migrasyon miktarları 364-642 ppb, 3000 ppm'lik polietilen numunelerinde gerçekleşen migrasyon miktarları ise 407-682 ppb 
şeklindedir. Bu koşullarda en yüksek migrasyon 682 ppb ile 30 günlük sürede 3000 ppm'lik polietilenden bulgura doğru iken, en düşük migrasyon ise 364 ppb ile 10 günlük sürede 1000 ppm'lik polietilenden kuru fasulyeye doğru olan migrasyondur. Irganox 1010'un 25 o ' 'de 1000 ppm'lik polietilen numunelerinden gerçekleşen geçişler ise $423-827$ ppb aralığında olup, 3000 ppm'lik polietilen numunelerinden gerçekleşen migrasyon miktarları ise 512-848 ppb aralığındadır. Bu koşullarda en yüksek migrasyon 848 ppb ile 30 günlük sürede 3000 ppm'lik polietilenden bulgura doğru olan migrasyon iken, en düşük migrasyon ise 423 ppb ile 10 günlük sürede 1000 ppm'lik polietilenden kuru fasulyeye doğru olan migrasyondur.

Anahtar Kelimeler: Polietilen paketleme, Irganoks 1010, Irganoks 1076, Migrasyon, Baklagil

\section{Introduction}

Plastic is a material consisting of any of synthetic or semi-synthetic organic compounds that can be molded into soft and solid objects. Plastic materials have become the most important commercial materials today because they are light, inexpensive, and easy to process and have many different uses. Because of these properties, it is frequently used in food packaging.

Polyolefins, together with the two most popular types, polypropylene and polyethylene, are the largest thermoplastic group since they can be used in a wide variety of applications. Polyolefins are polymers which consist of simple olefins such as ethylene, propylene, butene, isoprene or pentene, and copolymers thereof. Easy process ability, low cost, good chemical and physical properties make them the best choice for a wide range of plastic applications (Peacock, 2000). Antioxidants are used to increase the resistance of polyolefin containing materials to high temperature and UV light. When polyolefins are used in food packaging, these compounds or their degradation products may be transferred from plastics to foodstuffs during processing or storage. This situation may pose a risk to human health. Al-Malaika reviewed the effect of some of the parameters on the leaching of antioxidants in the human environment. Migration of antioxidants from packaging material to food product is determined by the interaction of a number of physical and chemical parameters, including the nature of the polymer and the food product; the molecular weight, volatility, and solubility of the antioxidant; temperature, light, irradiation and duration of contact with the food product. It provides important information about determination of antioxidant contents of polyolefinic materials, their potential migration and plastic quality measurements (Al-Malaika, 2004).

The most commonly used antioxidants to ensure long-term thermal stability of polyolefins are Irganox 1010 (pentaerythritoltetrakis(3-(3,5di-tert-butyl-4-hydroxyphenyl) propionate) and Irganox 1076 (octadecyl 3-(3,5-di-tert-butyl-4hydroxyphenyl) propionate). U.S. Food and Drug Administration (U.S. FDA) has set the tolerable daily intakes of Irganox 1010 and Irganox 1076 at $0.115 \mathrm{mg} / \mathrm{kg}$ body weight/day (U.S. FDA, 2015). The specific migration limit for Irganox 1010 and Irganox 1076 in food or food simulant was set at 6 $\mathrm{mg} / \mathrm{kg}$ food by the EU Commission (European Commission, 2003).

In the literature, there are many studies on the migration of antioxidants from polyolefinic materials into the various foods (Marcato et al., 2003; Burman et al., 2005; Dopico - Garcia et al., 2007; Galotto et al., 2011; Reinas et al., 2012; Karaca and Taşdemir, 2014; Coltro et al., 2014; McCombie et al., 2016; Vera et al., 2018). In these studies, commercial packaging materials were used to examine migration of the antioxidants. Cereals and legumes are widely consumed foods that help to sustain two - thirds of the worlds' population. Legumes are sold in polyethylene packaging. There is no study on the determination of antioxidant migration levels from polyethylene films into legumes in the literature.

In this study, migration levels of Irganox 1010 and Irganox 1076 from polyethylene packages into legumes such as rice, cracked wheat, corn, white beans, chickpea at two different temperatures (4 으 and $25 \stackrel{\circ}{\circ}$ ) and different storage times $(10,20,30$ days) were determined. 


\section{Materials and Methods}

\section{Reagents and Standards}

The studied migrants Irganox 1010 and Irganox 1076 were supplied from BASF Co. (Charlotte, USA). All chemicals were obtained from Merck (Darmstadt, Germany). All chemicals used were of analytical reagent grade and were at least $99.5 \%$ pure.

\section{Preparation of Masterbatch Forms}

The antioxidants in fine powder form were homogeneously mixed with pure granular low density polyethylene, then melted and regranulated. Masterbatch production machine is used for this. It is a GS- mach GSD-150 model single-screw extruder with a screw diameter of 25 $\mathrm{mm}$ and length of $40 \mathrm{~L} / \mathrm{D}$. Masterbatchs are prepared to be $10 \%$ antioxidant $+90 \%$ polyethylene $(w / w)$.

\section{Masterbatch and Polyethylene Granule Filling}

The masterbatch produced in granule form and the pure low density polyethylene ( $\mathrm{H} 2-8$ code product) raw material from PETKIM were filmed in the extrusion machine as a single layer pipe with a thickness of $60 \mu \mathrm{m}$ and a width of $30 \mathrm{~cm}$. Fong Kee single-screw extruder $(\mathrm{L}=400 \mathrm{~mm}$ and $L / D=20)$ was used. The screw speed was $90 \mathrm{rpm}$ at the constant temperature profile of $190 \stackrel{\circ}{ } \mathrm{C}$. The blow up ratio and draw down ratio were 2.5 and 23 , respectively. Corona treatment has not been applied to the product since it is not necessary. Polyethylene films containing 1000 ppm and 3000 ppm of Irganox 1010 and Irganox 1076 were prepared according to the information provided in the European Union practical guide for plastic packaging (European Commission, 2003). Polyethylene films are shown in Fig.1.

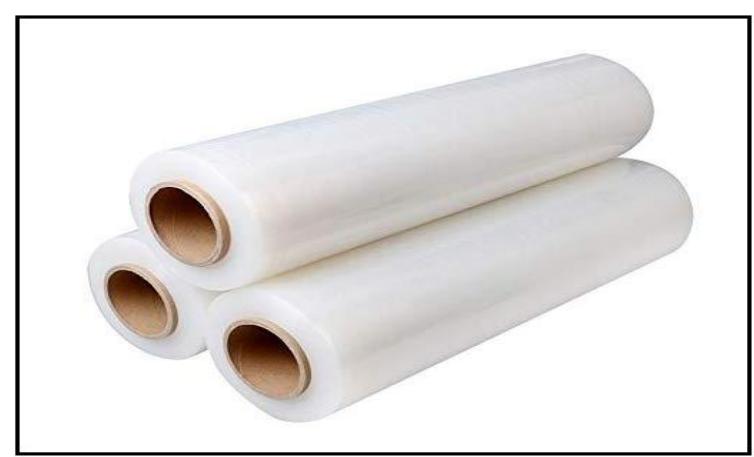

Figure 1. Polyethylene films

Şekil 1. Polietilen filmler

\section{Migration Tests}

Legume samples were sandwiched between two circular pieces of plastic, with a total surface area of $0.565 \mathrm{dm}^{2}$ (2 discs of $0.283 \mathrm{dm}^{2}$ each). Then, these sets were placed in $6 \mathrm{~cm}$ diameter petri dishes and stored at two different temperatures (4 으 and $25 \stackrel{\circ}{\circ}$ ) for 30 days according to the standard migration conditions of the US FDA (US FDA, 2015). The system used is shown schematically in Fig. 2.

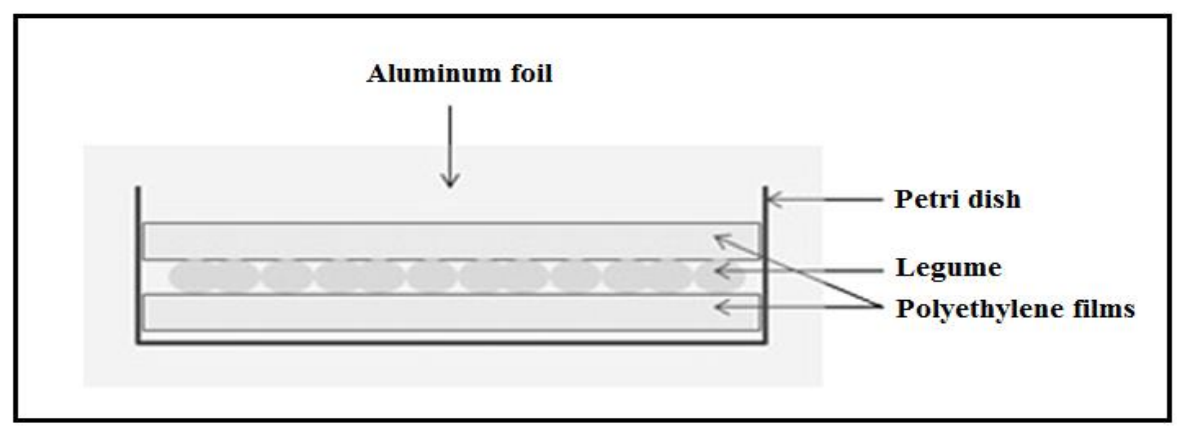

Figure 2. Migration cell Şekil 2. Migrasyon hücresi

\section{Quantification of Migrant in the Legumes}

The migrants from the legumes were extracted with $5 \mathrm{ml}$ isooctane for $2 \mathrm{~h}$. The legume samples were shaken in a vortex every 20 min to enhance extraction. Solid phase was separated by centrifugation at $4500 \mathrm{rpm}$ for $5 \mathrm{~min}$. Quantification was carried out using a Shimadzu QP2010-Ultra model gas chromatography - mass 
spectrometer. Calibration curves with 5 standards up to $1400 \mathrm{ng} \mathrm{ml}^{-1}$ for Irganox 1076 (correlation coefficient 0.9985) and Irganox 1010 (correlation coefficient 0.9999 ). The limits of detection were determined to be $40 \mathrm{ng} \mathrm{ml}^{-1}$ for Irganox 1076 and $20 \mathrm{ng} \mathrm{ml}^{-1}$ for Irganox 1010. Carbowax 20 M (30 m $x 0.25 \mathrm{~mm} ; 0.25 \mu \mathrm{m}$ ) column was used. The oven was held at an initial temperature of $50 \stackrel{\circ}{\circ}$ for 5


per minute, the end temperature of $200 \stackrel{\circ}{ } \mathrm{C}$ held for 20 minute. All analyses were repeated three times for each sample.

\section{Results and Discussion}

The amounts of migrants passing to the legumes contacted at $25^{\circ} \mathrm{C}$ and 4 ㅇ $\mathrm{C}$ for 10 days, 20 days and 30 days with PE samples prepared to contain 1000 ppm and 3000 ppm from Irganox 1076 are given in Table 1 and Table 2, respectively. It is observed that the migration levels of Irganox 1076 into legumes increased with increasing antioxidant content of polyethylene packages and storage time. It is thought that as the contact time increases, the migration value approaches towards an equilibrium value.

Irganox 1076 concentrations were found ranging from $350.83-1702.20 \mu \mathrm{g} \mathrm{kg}^{-1}$ and 222.34 $-1108.48 \mu \mathrm{g} \mathrm{kg}^{-1}$ in the legume samples during 30 days of storage at $25 \stackrel{\circ}{\circ}$ and $4 \stackrel{\circ}{\circ}$, respectively. The highest Irganox 1076 concentrations were determined in rice and cracked wheat, while the lowest Irganox 1076 concentration was determined in chickpea. These results are consistent with the contact time, the concentration of the migrant in the polyethylene and the size of the contact surface with the pulses. It is seen that the migration in all the legumes kept at $4 \stackrel{\circ}{\circ}$ is lower than those kept at 25 oC. Migration of Irganox 1076 to legumes stored at 4 으 for 30 days was found to be $25-40$ $\%$ less than those stored at $25 \stackrel{\circ}{ } \mathrm{C}$.

Table 1. Migration data depending on storage time at 25 ㅇ C for Irganox 1076 Çizelge 1. Irganoks 1076 için 25 oC'de depolama süresine bağlı migrasyon verileri

\begin{tabular}{|c|c|c|c|c|}
\hline \multirow[t]{2}{*}{$\begin{array}{l}\text { Legumes } \\
\text { Bakliyat }\end{array}$} & \multirow{2}{*}{$\begin{array}{c}\text { Amount of Irganox } \\
1076 \\
\text { Irganoks } 1076 \text { Miktarı } \\
\left(\mathrm{mg} \mathrm{kg}^{-1}\right)\end{array}$} & \multicolumn{3}{|c|}{$\begin{array}{l}\text { The amount of migrants passing to the legumes } \\
\text { Bakliyatlara geçen migrant miktarı } \\
\qquad\left(\mu \mathrm{g} \mathrm{kg}^{-1}\right)\end{array}$} \\
\hline & & $\begin{array}{l}\text { Tenth day } \\
\text { 10.gün }\end{array}$ & $\begin{array}{l}\text { Twentieth day } \\
\text { 20.gün }\end{array}$ & $\begin{array}{l}\text { Thirtieth day } \\
\text { 30.gün }\end{array}$ \\
\hline $\begin{array}{l}\text { Rice } \\
\text { Pirinç }\end{array}$ & 1000 & $1405.52 \pm 1.0$ & $1498.32 \pm 1.0$ & $1548.16 \pm 1.0$ \\
\hline $\begin{array}{l}\text { Rice } \\
\text { Pirinç }\end{array}$ & 3000 & $1523.80 \pm 1.0$ & $1644.83 \pm 1.0$ & $1702.20 \pm 1.0$ \\
\hline $\begin{array}{l}\text { Cracked wheat } \\
\text { Bulgur }\end{array}$ & 1000 & $808.26 \pm 0.7$ & $902.12 \pm 0.7$ & $953.30 \pm 0.8$ \\
\hline $\begin{array}{l}\text { Cracked wheat } \\
\text { Bulgur }\end{array}$ & 3000 & $939.09 \pm 0.9$ & $1068.20 \pm 1.0$ & $1125.60 \pm 1.0$ \\
\hline $\begin{array}{l}\text { Corn } \\
\text { Misır }\end{array}$ & 1000 & $652.75 \pm 0.6$ & $778.52 \pm 0.6$ & $833.14 \pm 0.7$ \\
\hline $\begin{array}{l}\text { Corn } \\
\text { Misır }\end{array}$ & 3000 & $701.56 \pm 0.6$ & $824.16 \pm 0.7$ & $886.98 \pm 0.7$ \\
\hline $\begin{array}{l}\text { White beans } \\
\text { Kuru fasulye }\end{array}$ & 1000 & $587.16 \pm 0.6$ & $698.16 \pm 0.6$ & $748.32 \pm 0.6$ \\
\hline $\begin{array}{l}\text { White beans } \\
\text { Kuru fasulye }\end{array}$ & 3000 & $690.30 \pm 0.6$ & $801.24 \pm 0.7$ & $856.13 \pm 0.7$ \\
\hline $\begin{array}{l}\text { Chickpea } \\
\text { Nohut }\end{array}$ & 1000 & $350.83 \pm 0.5$ & $467.63 \pm 0.5$ & $507.51 \pm 0.5$ \\
\hline $\begin{array}{l}\text { Chickpea } \\
\text { Nohut }\end{array}$ & 3000 & $371.72 \pm 0.5$ & $498.32 \pm 0.5$ & $549.85 \pm 0.5$ \\
\hline
\end{tabular}


Table 2. Migration data depending on storage time at 4 으 for Irganox 1076 Çizelge 2. Irganoks 1076 için 4 o C'de depolama süresine bağlı migrasyon verileri

\begin{tabular}{|c|c|c|c|c|}
\hline $\begin{array}{l}\text { Legumes } \\
\text { Bakliyat }\end{array}$ & $\begin{array}{c}\text { Amount of Irganox } \\
1076 \\
\text { Irganoks } 1076 \text { Miktarı } \\
\left(\mathrm{mg} \mathrm{kg}^{-1}\right)\end{array}$ & $\begin{array}{c}\text { Tenth day } \\
\text { 10.gün }\end{array}$ & $\begin{array}{l}\text { migrants passing } \\
\text { anoks } 1076 \text { Mikt } \\
\left(\mu \mathrm{kg}^{-1}\right) \\
\text { Twentieth day } \\
\text { 20.gün }\end{array}$ & $\begin{array}{l}\text { Thirtieth day } \\
\text { 30.gün }\end{array}$ \\
\hline $\begin{array}{l}\text { Rice } \\
\text { Pirinç }\end{array}$ & 1000 & $802.50 \pm 0.7$ & $890.48 \pm 0.7$ & $942.26 \pm 0.8$ \\
\hline $\begin{array}{l}\text { Rice } \\
\text { Pirinç }\end{array}$ & 3000 & $933.00 \pm 0.8$ & $1052.24 \pm 1.0$ & $1108.48 \pm 1.0$ \\
\hline $\begin{array}{l}\text { Cracked wheat } \\
\text { Bulgur }\end{array}$ & 1000 & $569.18 \pm 0.6$ & $659.54 \pm 0.6$ & $710.44 \pm 0.6$ \\
\hline $\begin{array}{l}\text { Cracked wheat } \\
\text { Bulgur }\end{array}$ & 3000 & $700.98 \pm 0.8$ & $826.52 \pm 0.7$ & $888.32 \pm 0.7$ \\
\hline $\begin{array}{l}\text { Corn } \\
\text { Misır }\end{array}$ & 1000 & $514.36 \pm 0.5$ & $603.56 \pm 0.6$ & $652.16 \pm 0.6$ \\
\hline $\begin{array}{l}\text { Corn } \\
\text { Misır }\end{array}$ & 3000 & $568.44 \pm 0.5$ & $658.80 \pm 0.6$ & $710.50 \pm 0.6$ \\
\hline $\begin{array}{l}\text { White beans } \\
\text { Kuru fasulye }\end{array}$ & 1000 & $426.19 \pm 0.5$ & $513.46 \pm 0.5$ & $561.85 \pm 0.5$ \\
\hline $\begin{array}{l}\text { White beans } \\
\text { Kuru fasulye }\end{array}$ & 3000 & $548.25 \pm 0.5$ & $638.66 \pm 0.6$ & $689.60 \pm 0.6$ \\
\hline $\begin{array}{l}\text { Chickpea } \\
\text { Nohut }\end{array}$ & 1000 & $222.34 \pm 0.3$ & $312.52 \pm 0.5$ & $363.48 \pm 0.5$ \\
\hline $\begin{array}{l}\text { Chickpea } \\
\text { Nohut }\end{array}$ & 3000 & $256.48 \pm 0.3$ & $344.15 \pm 0.5$ & $395.72 \pm 0.5$ \\
\hline
\end{tabular}

Table 3. Migration data depending on storage time at 25 으 for Irganox 1010 Çizelge 3. Irganoks 1010 için 25 oC'de depolama süresine bağlı migrasyon verileri

\begin{tabular}{|c|c|c|c|c|}
\hline \multirow[t]{2}{*}{$\begin{array}{l}\text { Legumes } \\
\text { Bakliyat }\end{array}$} & \multirow{2}{*}{$\begin{array}{c}\text { Amount of Irganox } \\
1010 \\
\text { Irganox } 1010 \text { Miktarı } \\
\left(\mathrm{mg} \mathrm{kg}^{-1}\right)\end{array}$} & \multicolumn{3}{|c|}{$\begin{array}{c}\text { The amount of migrants passing to the legumes } \\
\text { Bakliyatlara Geçen Migrant Miktarı } \\
\qquad\left(\mu \mathrm{kg}^{-1}\right)\end{array}$} \\
\hline & & $\begin{array}{c}\text { Tenth day } \\
\text { 10.gün }\end{array}$ & $\begin{array}{c}\text { Twentieth day } \\
\text { 20.gün }\end{array}$ & $\begin{array}{c}\text { Thirtieth day } \\
\text { 30.gün }\end{array}$ \\
\hline Rice & 1000 & $518.70 \pm 0.5$ & $642.62 \pm 0.6$ & $693.44 \pm 0.6$ \\
\hline Pirinç & & & & \\
\hline $\begin{array}{l}\text { Rice } \\
\text { Pirinç }\end{array}$ & 3000 & $647.64 \pm 0.6$ & $758.22 \pm 0.6$ & $800.50 \pm 0.7$ \\
\hline $\begin{array}{l}\text { Cracked wheat } \\
\text { Bulgur }\end{array}$ & 1000 & $656.14 \pm 0.6$ & $782.15 \pm 0.6$ & $827.58 \pm 0.7$ \\
\hline $\begin{array}{l}\text { Cracked wheat } \\
\text { Bulgur }\end{array}$ & 3000 & $680.11 \pm 0.6$ & $800.30 \pm 0.7$ & $848.12 \pm 0.7$ \\
\hline $\begin{array}{l}\text { Corn } \\
\text { Misır }\end{array}$ & 1000 & $470.49 \pm 0.5$ & $590.35 \pm 0.6$ & $632.14 \pm 0.6$ \\
\hline $\begin{array}{l}\text { Corn } \\
\text { Misır }\end{array}$ & 3000 & $556.32 \pm 0.5$ & $670.20 \pm 0.6$ & $710.22 \pm 0.6$ \\
\hline $\begin{array}{l}\text { White beans } \\
\text { Kuru fasulye }\end{array}$ & 1000 & $423.67 \pm 0.5$ & $544.20 \pm 0.5$ & $608.12 \pm 0.6$ \\
\hline $\begin{array}{l}\text { White beans } \\
\text { Kuru fasulye }\end{array}$ & 3000 & $512.20 \pm 0.5$ & $640.12 \pm 0.6$ & $700.26 \pm 0.6$ \\
\hline $\begin{array}{l}\text { Chickpea } \\
\text { Nohut }\end{array}$ & 1000 & $485.37 \pm 0.5$ & $600.18 \pm 0.6$ & $642.30 \pm 0.6$ \\
\hline $\begin{array}{l}\text { Chickpea } \\
\text { Nohut }\end{array}$ & 3000 & $560.82 \pm 0.5$ & $668.42 \pm 0.6$ & $712.10 \pm 0.6$ \\
\hline
\end{tabular}

The amounts of migrants passing to the legumes contacted at $25^{\circ} \mathrm{C}$ and 4 oC for 10 days, 20 days and 30 days with PE samples prepared to contain 1000 ppm and 3000 ppm from Irganox 1010 are given in Table 3 and Table 4, respectively. Irganox 1010 concentrations were found ranging from $423.67-848.12 \mu \mathrm{g} \mathrm{kg}^{-1}$ in the legume samples during 30 days of storage at 25 oc. The highest Irganox 1010 concentration was determined in cracked wheat, while the lowest 
Irganox 1010 concentration was determined in white beans. Irganox 1010 concentrations were found ranging from $364.58-682.20 \mu \mathrm{g} \mathrm{kg}^{-1}$ in the legume samples during 30 days of storage at 4 ㅇ․ Similarly, the highest Irganox 1010 concentration was determined in cracked wheat, while the lowest Irganox 1010 concentration was determined in white beans. Migration of Irganox 1010 to legumes stored at 4 으 $\mathrm{C}$ for 30 days was found to be $15-25 \%$ less than those stored at 25 oC.

Table 4. Migration data depending on storage time at 4 으 for Irganox 1010

Çizelge 4. Irganoks 1010 için 4 ㅇ'de depolama süresine bağlı migrasyon verileri

\begin{tabular}{|c|c|c|c|c|}
\hline $\begin{array}{l}\text { Legumes } \\
\text { Bakliyat }\end{array}$ & $\begin{array}{l}\text { Amount of Irganox } \\
1010 \\
\text { Irganox } 1010 \text { Miktarı } \\
\left(\mathrm{mg} \mathrm{kg}^{-1}\right)\end{array}$ & $\begin{array}{c}\text { Tenth day } \\
\text { 10.gün }\end{array}$ & $\begin{array}{l}\text { migrants passin } \\
\text { lara Geçen Migr } \\
\left(\mu \mathrm{kg}^{-1}\right) \\
\text { Twentieth day } \\
\text { 20.gün }\end{array}$ & $\begin{array}{l}\text { Thirtieth day } \\
\text { 30.gün }\end{array}$ \\
\hline Rice & 1000 & $386.12 \pm 0.5$ & $477.22 \pm 0.5$ & $526.44 \pm 0.5$ \\
\hline Pirinç & & & & \\
\hline $\begin{array}{l}\text { Rice } \\
\text { Pirinç }\end{array}$ & 3000 & $494.36 \pm 0.5$ & $582.14 \pm 0.5$ & $630.25 \pm 0.6$ \\
\hline $\begin{array}{l}\text { Cracked wheat } \\
\text { Bulgur }\end{array}$ & 1000 & $502.18 \pm 0.5$ & $592.46 \pm 0.6$ & $642.50 \pm 0.6$ \\
\hline $\begin{array}{l}\text { Cracked wheat } \\
\text { Bulgur }\end{array}$ & 3000 & $544.80 \pm 0.5$ & $634.35 \pm 0.6$ & $682.20 \pm 0.6$ \\
\hline $\begin{array}{l}\text { Corn } \\
\text { Misır }\end{array}$ & 1000 & $395.42 \pm 0.5$ & $485.50 \pm 0.5$ & $535.62 \pm 0.5$ \\
\hline $\begin{array}{l}\text { Corn } \\
\text { Misır }\end{array}$ & 3000 & $442.15 \pm 0.5$ & $535.17 \pm 0.5$ & $583.28 \pm 0.5$ \\
\hline $\begin{array}{l}\text { White beans } \\
\text { Kuru fasulye }\end{array}$ & 1000 & $364.58 \pm 0.5$ & $454.42 \pm 0.5$ & $491.96 \pm 0.5$ \\
\hline $\begin{array}{l}\text { White beans } \\
\text { Kuru fasulye }\end{array}$ & 3000 & $407.18 \pm 0.5$ & $498.30 \pm 0.5$ & $549.27 \pm 0.5$ \\
\hline $\begin{array}{l}\text { Chickpea } \\
\text { Nohut }\end{array}$ & 1000 & $398.22 \pm 0.5$ & $487.85 \pm 0.5$ & $536.40 \pm 0.5$ \\
\hline $\begin{array}{l}\text { Chickpea } \\
\text { Nohut }\end{array}$ & 3000 & $461.46 \pm 0.5$ & $542.13 \pm 0.5$ & $593.58 \pm 0.5$ \\
\hline
\end{tabular}

Many factors need to be controlled to ensure that food is delivered to the consumer in a healthy manner. These factors start with the production process of food and continue with packaging and sales. One of the most important factors is packaging. Although packaging materials are compatible with food and are not intended to interact with food, it is also known that there is no practically inert packaging. In this case, the most important criterion is the physical contact and chemical interactions between foods and packaging material.

Irganox 1010 and Irganox 1076 are the most widely used additives in polyethylene packages. Although there are some studies on the migration of these additives in the literature (Chang et al., 2019; Dopico - Garcia et al., 2003; Dopico Garcia et al., 2007; Galotto et al., 2011; Beldi et al., 2012), there is no study on the migration from polyethylene packages containing controlled amounts of additives into the foods.

\section{Conclusion}

In this study, the controlled forms and contents of the polyethylene packages containing Irganox 1010 and Irganox 1076 were contacted with solid legumes at different temperatures and times and the migration amounts were measured. Migration levels of both Irganox 1076 and Irganox 1010 into legumes increased with increasing antioxidant content of polyethylene packages and storage time. Furthermore, it has been determined that migrations occurring in refrigerated samples are less than samples stored at room temperature. Thus, temperature has similar impact on the migration of both Irganox 
1076 and Irganox 1010 when migrating into the same matrix.

Specific migration levels were established at 6 mg/kg for Irganox 1076 and Irganox 1010 by European legislation. The determined concentrations of Irganox 1076 and Irganox 1010 did not exceed its specific migration limit. As a result, we can say that these antioxidants are not a risk factor for human health at the present time.

\section{Acknowledgements}

This research (14301) was supported by the Scientific Research Projects Coordination Unit of Hatay Mustafa Kemal University. The authors would like to thank the Scientific Research Projects Coordination Unit of Hatay Mustafa Kemal University for financial support.

\section{Compliance with Ethical Standards}

Conflict of Interest: The authors declare that they have no conflict of interest.

Ethical approval: For this type of study formal consent is not required.

\section{References}

Al-Malaika, S. (2004). Perspectives in Stabilization of Polyolefins. Advances in Polymer Science, 169, 121150.

Beldi, G., Pastorelli, S., Franchini, F., Simoneau, C. (2012). Time and Temperature Dependant Migration Studies of Irganox 1076 from Plastics into Foods and Food Simulants. Food Additives and Contaminants, 29(5), 836-845.

Burman, L., Albertsson, A. C., \& Hoglund, A. (2005). SolidPhase Microextraction for Qualitative and Quantitative Determination of Migrated Degradation Products of Antioxidants in an Organic Aqueous Solution. Journal of Chromatography A, 1080, 107116.

Chang, Y., Kang, K., Park, S. J., Choi, J. C., \& Kim, M. (2019). Experimental and Theoretical Study of Polypropylene:Antioxidant Migration with Different Food Simulants and Temperatures. Journal of Food Engineering, 244, 142-149.
Coltro, L., Pitta, J. B., Da Costa, P. A., Perez, M. A. F., De Araújo, V. A., \& Rodrigues, R. (2014). Migration of Conventional and New Plasticizers from PVC Films into Food Simulants: A Comparative Study. Food Control, 44, 118-129.

Dopico - Garcia, M. S., Lopez - Vilarino, J. M., Gonzales Rodriguez, M. V. (2003). Determination of Antioksidant Migrations Levels from Low Density Polyethylene Films into Food Simulants. Journal of Chromatography A, 1018 (1), 53-62.

Dopico - Garcia, M. S., Lopez - Vilarino, J. M., \& Gonzalez Rodriguez, M. V. (2007). Antioxidant Content of and Migration from Commercial Polyethylene, Polypropylene, and Polyvinyl Chloride Packages. Journal of Agricultural and Food Chemistry, 55, 32253231.

European (EU) Commission. (2003). A Practical Guide for Users of European Directives. SANCO D3 / LR D. https://www.esac.pt/noronha/manuais/ practical_guide_en_sanco_d3_Ird_ 0 4\%202003. pdf.

Galotto, M. J., Torres, A., Guarda, A., Moraga, N., Romero, J. (2011). Experimental and Theoretical Study of LDPE Versus Different Concentrations of Irganox 1076 and Different Thickness. Food Research International, 44, 566-574.

Karaca, G., \& Taşdemir, Y. (2014). Migration of PAHs in Food Industry Sludge to the Air During Removal by UV and $\mathrm{TiO}_{2}$. Science of the Total Environment, 488489, 356-361.

Marcato, B., Guerro, S., Vianello, M., \& Scalia, S. (2003). Migration of Antioxidant Additives from Various Polyolefinic Plastics into Oleaginous Vehicles. International Journal of Pharmaceutics, 257, 217225.

McCombie, G., Hotzer, K., Daniel, J., Biedermann, M., Eicher, A., \& Grob, K. (2016). Compliance Work for Polyolefins in Food Contact: Results of an Official Control Campaign, Food Control, 59, 793-800.

Peacock, A.J. (2000). Handbook of Polyethylene, Marcel Dekker, New York.

Reinas, I., Oliveira, J., Pereira, J., Machado, F., \& Poças, M. F. (2012). Migration of Two Antioxidants from Packaging into a Solid Food and into Tenax. Food Control, 28, 333-337.

US FDA, 2015. Guidance for industry: preparation of premarket submissions for food contact substances: Chemistry recommendations. Available from: http://www.fda.gov/Food/GuidanceRegulation/Guid anceDocumentsRegulatorylnformation/IngredientsA dditivesGRASPackaging/ucm081818.htm.

Vera, P., Canellas, E., \& Nerin, C. (2018). Identification of Non Volatile Migrant Compounds and NIAS in Polypropylene Films Used as Food Packaging Characterized by UPLC-MS/QTOF. Talanta, 188, 750-762. 